ISSN: 0213-2079 - ISSN electrónico: 2386-3889

DOI: https://doi.org/10.14201/shhmo201941271101

\title{
PODER Y CONFLICTO SOCIAL EN EL CABILDO DE LA CATEDRAL DE LEÓN A FINALES DEL SIGLO XVII
}

\section{Power and social conflict in the Cathedral Chapter in León in the late 17th century}

\author{
María José PÉREZ ÁLVAREZ \\ Universidad de León \\ ORCID: 071-1011-5490-3895
}

Fecha de envío: 15 de octubre de 2019

Fecha de aceptación: 19 de noviembre de 2019

RESUMEN: Tras el fallecimiento del deán del cabildo leonés D. Vicente de la Iglesia, se abrió en la institución un periodo de inestabilidad que acabó generando una división entre los capitulares ${ }^{1}$. La primera fragmentación surgió cuando no aceptaron a la persona que había nombrado el obispo para ocupar el puesto, pero las verdaderas tensiones de desencadenaron tras presentar la bula el leonés D. Antonio Castañón Villafañe. Los estatutos de limpieza de sangre le proporcionaron al cabildo el medio para intentar reprobarlo. Un largo expediente, en el que se trató demostrar que sobre esa familia recaía la mácula judía y que está cuajado de exigencias documentales, dobles declaraciones o acusaciones infundadas. Solamente la intervención del nuncio logró elevar al deanato a D. Antonio, lo que no supuso el fin del proceso, pues las apelaciones, por ambas partes, presidieron las juntas capitulares hasta el fallecimiento de aquel, tres años después de tomar posesión.

Palabras clave: León; cabildo de la catedral; deán; conflicto; siglo XVII.

1. Este trabajo forma parte del proyecto de investigación Clero y sociedad en el noroeste de la Península Ibérica (siglos XV-XIX) (HAR2017-82473-P), financiado por el Ministerio de Economía y Competitividad.

Ediciones Universidad de Salamanca / @@ Stud. his., H. ${ }^{a}$ mod., 41, n. 2 (2019), pp. 71-101 


\begin{abstract}
The death of D. Vincent de la Iglesia, the dean of the cathedral chapter in León, ushered in a period of instability that eventually sowed dissent in the chapter. The first conflict arose when the chapter refused to accept the person the bishop had selected to occupy the post, but the deepest discord was triggered when a man from León, D. Antonio Castanon Villafañe, presented the papal bulls. The statutes of purity of blood provided the chapter with an excuse to reject him. A lengthy hearing ensued seeking to demonstrate that his family had Jewish ancestry, which was plagued with demands for documentary evidence, duplicated statements and unfounded accusations. It was only through the intervention of the papal nuncio that D. Antonio was appointed dean; however, this did not put an end to the dispute, since appeals by both parties predominated chapter meetings until his death three years after taking possession.
\end{abstract}

Keywords: León; cathedral chapter; dean; conflict; the 17th century.

El 26 de febrero de $1684^{2}$ falleció el deán de la santa iglesia de León, D. Vicente de la Iglesia, a partir de ese momento comenzó un lago periodo de rivalidad entre los capitulares que acabó desembocado en fuertes tensiones. Apenas transcurrido un mes de la muerte de aquel, se presentó un título, despachado por el obispo Aparicio, a favor de D. Marcelo de la Puente para ocupar el deanato. D. Antonio Miranda, como subcolector de la Real Cámara Apostólica, requirió al cabildo que no lo admitiese, por estar esa prebenda reservada a la Santa Sede y pidió que se pusiera contradicción y protesta. Trataron de llegar a un acuerdo con el prelado, siempre defendiendo que la prebenda de deán era «notoriamente afecta» a la sede apostólica, pero las conversaciones no fueron fructíferas. En el libro de tabla de ese periodo D. Marcelo de la Iglesia no aparece registrado, por lo que no logró tampoco ocupar un canonicato ${ }^{3}$.

Más problemático fue el proceso que tuvo que superar el siguiente candidato a deán, D. Antonio Castañón Villafañe, clérigo de menores, doctorado en leyes y cánones por la Universidad de la Sapienza en 1685 (Ramis, 2017:194-195), hijo del que había sido regidor perpetuo de León, D. Fernando Castañón, hermano del sucesor de aquel y pariente de otros regidores de la ciudad ${ }^{4}$.

2. Archivo Histórico de la Catedral de León (A.H.C.L.) L.10.007.

3. A.H.C.L, L. 10.742.

4. Sobre la formación del patrimonio de la familia Castañón, consultar Castillo, 2008:201220. 
MARÍA JOSÉ PÉREZ ÁLVAREZ

PODER Y CONFLICTO SOCIAL EN EL CABILDO DE LA CATEDRAL DE LEÓN A FINALES DEL SIGLO XVII

\section{LAS PRUEBAS DE LIMPIEZA DE SANGRE DE D. ANTONIO CASTAÑÓN VILLAFAÑE (1685-1689)}

\subsection{El estatuto de limpieza de sangre del cabildo leonés}

A lo largo de toda la Edad Moderna, era condición indispensable demostrar que corría sangre de cristianos viejos por las venas de los aspirantes a ingresar en la administración civil y eclesiástica, en determinadas cofradías, conventos o colegios. Superar aquella prueba ${ }^{5}$ era, además, signo de distinción social (Barrio, 1982: 293). Por supuesto, todo aquel que quisiera entrar a formar parte del cabildo leonés, independientemente del puesto que pretendiera ${ }^{6}$ dentro de su jerarquía ${ }^{7}$, debía salvarlas. En la iglesia catedral de León, los primeros estatutos de limpieza de sangre fueron elaborados en $1525^{8}$, por el obispo D. Pedro Manuel, y ratificados unos años después por el prelado Pérez de Temiño. A raíz de la confirmación de los mismos, en 1549, se estimó que no estaban siendo respetados con el mismo rigor con el que se habían elaborado9. Por su parte, el cabildo, de acuerdo con el Ilmo. D. Andrés Cuesta, y teniendo presentes los estatutos anteriores ${ }^{10}$, amplió su contenido en 1561, tomando como referente los de Toledo ${ }^{11}$. El mismo obispo, en el alegato

5. Su contenido formaba parte de una colección de medidas jurídicas que reforzaban el concepto de linaje surgido en la etapa final de la edad Media. CONTRETAS, 1991: 62 y ss.

6. Los cabildos fueron más tardíos en adoptar los estatutos de limpieza de sangre que otras comunidades religiosas e, incluso, algunos reacios. DOMINGUEZ, 1991:62-65; VÁZQUEZ, 1999:599; SICROFF, 1985: 120-122; LATORRE, 1992:282; OLIVARES, 1995: 34-35; MARÍN, 1998: 66-70; QUINTANA, 2004:34; IGLESIAS, 1996: 422; HERNÁNDEZ, 1996: 68; CÁNOVAS, 1994:236; RIBERIRO 2010:74; AUGUSTO, 1979:74. En alguno, como el de Murcia o Ávila, solamente se aplicaban a los canonicatos de oficio. HERNÁNDEZ, 1996:73 y 76-79.

A.H.C.L. Doc. 13.265.

7. Cofrades, bachilleres, capellanes cantores o pertigueros tenían que superar la prueba. Como ha señalado GUILLÉN, (207:116), refiriéndose a la relación entre nobleza y limpieza de sangre: «adquiere en los espacios del Mediterráneo occidental un carácter mítico, una conciencia propia que afecta a todas las facetas de la vida del hombre, y convierte en su antónimo la consideración del valor individual del individuo». Por su parte, Hernández, señalaba que las pruebas servían para mantener el honor de la institución y las que adoptaron los estatutos pretendían «aproximarse en honor-prestigio a aquellas que ya los poseían». A los cabildos les proporcionaban «prestigio y reconocimiento». HERNÁNDEZ, 1996: 66-67, HERNÁNDEZ, 2011:20; HERNÁNDEZ y RUIZ, 2003, 35-56 y 39-40.

8. GARCÍA (2004:556), Consideró que el estatuto fue resultado de querer, el cabildo, revestirse de «otro requisito social que estaba convirtiéndose en título de legitimidad».

9. A.H.C.L. Doc. 13.265.

10. Fueron aprobados el 1 de enero de 1562, por Bula del papa Pio IV. A.H.C.L. Docs. 4106, 4107 y 10.887.

11. Aquel fue el primer estatuto de limpieza de sangre que hubo en España, si bien su aplicación en el cabildo, salpicada de resistencias, fue posterior. SICROFF, 1985: 56 y 134-170. 
previo, consideró que gran parte de los problemas y bullicios que surgían en las universidades, ayuntamientos y otras congregaciones se originaban por la presencia en ellos de individuos «con origen de judíos, conversos, moros o herejes, quemados o ensambenitados por el Santo Oficio de la Inquisición». Ponía como ejemplo de buen funcionamiento los colegios, cofradías y otras instituciones seculares que, por medio de los estatutos, excluían a todos los aspirantes que estuvieran tocados por aquel tipo de mácula. También justificaba la necesidad de los mismos por «la miseria de los nuevos tiempos en los cuales se han levantado tantas herejías, en las cuales los más que se han hallado culpados...han sido judíos marranos, conversos o moros...». Tras esta justificación, ordenó que en adelante todos los que fueran admitidos para desempeñar una dignidad, canonjía, prebenda, capellanía, ración, los cantores o cualquier otro beneficio que tuviera anejo la cura de almas, debían cumplir tres requisitos: nobleza, estar graduados en alguna universidad general y ser cristianos viejos. Si bien, la carencia de los dos primeros quedaba compensada por el tercero. A partir de entonces, todos los pretendientes a alguno de aquellos beneficios, tras presentar la bula que les daba acceso al puesto, que sería examinada y validada por la diputación capitular que a continuación la pasaba al cabildo, debía superar las pruebas de limpieza de sangre. Las investigaciones pertinentes de la familia del candidato se encomendaban a un canónigo, acreditado como cristiano viejo que estuvieran en turno, o en «el cántaro», y al provisor del obispado. Si bien, prácticamente, todas fueron confiadas a dos canónigos. Por supuesto, ninguno de los calificadores podía tener relación de parentesco ni geográfica con el pretendiente. En este sentido, quedaban excluidos aquellos cuya naturaleza estuviera dentro de un radio de «diez leguas» de la del candidato ${ }^{12}$. Para recabar los datos que estimaban que eran necesarios para cumplir escrupulosamente su cometido, debían desplazarse ${ }^{13}$ al lugar de origen de los padres, e incluso abuelos del examinado si lo juzgaban preciso. El procedimiento, que quedó establecido en el siglo XVI, se fue perfilando y recordando la obligatoriedad de su aplicación en reuniones capitulares posteriores ${ }^{14}$.

El estatuto del siglo XVI, tomó una nueva dirección en 1669, de la mano del obispo Fray Juan de Toledo, consensuado con el cabildo. A lo ya dispuesto en los

12. En 1645, 1670, 1671, 1701 o 1706, se recordó la prohibición de informantes cuyo origen estuviera dentro de las diez leguas de la localidad de origen de los padres. «A fin de evitar pasión, interés u otras circunstancias». A.H.C.L. 10.0011, 10.022 y 10.038. Al menos, desde 1671, no podían formar parte de la comisión juzgadora aquellos prebendados que no hubieran cumplido los dos primeros años de residencia; y unos años después, se prohibió a «los familiares del señor obispo» el participar en las pruebas de otro familiar. A.H.C.L. Leg. 9.994 y 10.038 .

13. Largos desplazamientos, sobre todo cuando los ascendentes eran de localidades lejanas entre sí, junto a imprevistos, podían ocasionar «un descalabro económico de la familia». IGLESIAS, 1996: 423.

14. Sobre las fases del proceso consultar HERNÁNDEZ, 1996: 91 y ss. 
anteriores, se añadía que, a partir de entonces, podían embarazar las aspiraciones del candidato los oficios de los progenitores y abuelos «que según fueros y leyes de estos reinos induce infamia» ${ }^{15}$. Esta nueva normativa, que dificultaba el acceso a los puestos más elevados del cabildo, no así a bachilleres y racioneros ${ }^{16}$, dejaba a los aspirantes un pequeño resquicio, pues, en caso de ser rechazados por el cabildo, en base a alguno de aquellos motivos, debían admitirlos en el momento en que lograran la primera sentencia judicial favorable. En este sentido, también les resultaba de mucha utilidad la Pragmática de $1623^{17}$, relativa a la calificación de nobleza y limpieza de sangre demostrando tres actos positivos, que, a pesar de ser denostada, todos los canónigos sometidos a esta investigación en el cabildo leonés, que podían presentarlos, continuaron haciéndolo y pidiendo que se tuvieran en cuenta (Sicroff, 1979: 261).

Centrándonos en los expedientes de limpieza de sangre, que se conservan en el archivo catedralicio de León, elaborados en la segunda mitad del siglo XVII ${ }^{18}$, la acusación de tener algún ancestro judío o judaizante aparece en cinco ${ }^{19}$ : los de

15. «...ejecutor público de justicia, pregonero, mozo de parada, mozo de la plaza, contador de carne y pescado, guarda público del campo y otros semejantes a estos hayan de empecer y embarazar la entrada en nuestra Santa Iglesia. Así en la persona de los pretendientes como en la de sus padres y abuelos paternos y maternos y se haya de resistir en la forma que se acostumbra a los defectuosos de limpieza. Y en los oficios viles, como son zapatero, curtidor, velero de sebo, pastelero, bodegonero, mesonero público y otros de este género haya de embarazar con la misma extensión a padres y abuelos». A.H.C.L. Doc. 10919.

16. Un siglo después, en 1769, los bachilleres y racioneros quedaron también exentos de las pruebas de limpieza de sangre. A.H.C.L. Doc. 4.392.

17. La Pragmática de 1623, reafirmada por la Cédula de 1638, dirigida a los pretendientes de los consejos de inquisición, ordenes, colegios mayores y demás comunidades de estatuto, recogía que «deseando obviar los daños que en semejantes juicios suelen padecer los pretendientes, ocasionados de la malicia de sus émulos, que sin defensa ni contradicción ejecutan sus venganzas: mandé que con tres actos positivos obtenidos en los tribunales y comunidades y con las demás calidades expresadas en dicha ley, tuvieran fuerza y autoridad de cosa juzgada y causen derecho Real a los interesados, revelándolos de otra prueba». Esos actos positivos podían ser de ascendientes, colaterales o transversales que descendieran de un tronco común.

18. Tas el fracaso de Olivares por abrir la sociedad, la crisis que se vivió en el siglo XVII la volvió más intolerante para «conservar lo único que tenía...la condición de cristiano viejo, limpio de sangre, sin mácula ni raza de judíos»; el «mantenimiento del honor por parte del cristiano viejo en su porfía con el cristiano nuevo se hizo reactivando nuevamente la imperecedera mácula del linaje». HERNÁNDEZ, 2011: 251, 256 y 258.

19. Quizá, en épocas precedentes pudo haber un número mayor de candidatos que se enfrentaran a aquella acusación. De hecho, los momentos más críticos en este sentido, de haberse producido, tendrían lugar cuando aún no había transcurrido un número suficiente de años, y generaciones, para que socialmente se fuera diluyendo la mácula. A tener en cuenta, también, es que se conservan los expediente de los que superaron las pruebas. IGLESIAS, 2011:28. La participación de familias conversas en los cabildos era una manera de fomentar su integración social. CABEZA, 1995: 118-122. 
D. Blasco Marcelo de Quiñones, natural de León, en 1661; D. Jerónimo Bedoya Hernando, de Dobres (Valle de Liébana), en 1671; D. Antonio Castañón Villafañe, leonés, en 1688; D. Melchor Gallo Velasco, de Saldaña al año siguiente; y D. Antonio Martínez Sánchez, de Villalón de Campos ${ }^{20}$, en 1697. En casi todos, las inquinas entre familias se escondían detrás de «los murmullos» y las «habladurías» que provocaron no pocos problemas a los aspirantes al ahora de calificarse.

\subsection{El expediente de D. Antonio Castañón Villafañe}

D. Antonio Castañón Villafañe fue provisto, por el papa Inocencio XI, para ocupar una canonjía y el deanato del cabildo de la catedral de León a la edad de 24 años. Su nombramiento no tuvo buena acogida entre los capitulares, que utilizaron todos los recursos a su alcance para evitar que tomara posesión de la dignidad y prebenda. Ese rechazo, que provocó duros enfrentamientos entre los capitulares ${ }^{21}$, dio lugar a una minuciosa y viciada investigación de sus orígenes familiares, que tuvo comienzo en $1685^{22}$.

El cabildo comenzó negándose a recoger la bula apostólica ${ }^{23}$ de D. Antonio, y solo tras la intervención del nuncio se vio obligado a aceptarla. Incluso antes de que aquella le llegara, en el momento que tuvo noticias de la provisión, ya puso en marcha todo un operativo para frenar la incorporación de Castañón a la institución. Una de sus primeras actuaciones, «mediante autos secretos», fue pedir al obispo que solicitara al Papa que suspendiera la designación, alegando que no había necesidad de poner en entredicho a su familia, sacando un pasado genealógico no acorde con lo que exigían los estatutos de limpieza de sangre. Se referían a los problemas que había tenido el padre del candidato para optar al hábito de Alcántara. Para reforzar su petición, elaboraron, en abril de 1685, un expediente de limpieza de sangre en el que solo fueron examinados canónigos.

El 3 de mayo de 1686 D. Antonio entregó el poder para que se comenzara a elaborar su expediente de limpieza de sangre y cuatro días después se celebró

20. Como ha señalado Domínguez Ortiz, en las localidades pequeñas era más difícil la imparcialidad de los testigos que en las grandes. DOMINGUEZ, 1991: 75-76.

21. DÍAZ, 2013: 543-576.

22. A.H.C.L. Exps. 562 y 571.

23. «...por ventura, los prebendados de León tienen estatuto para no admitir Bulas despachadas en la forma ordinaria por su Santidad, que es legítimo colador de ellas, pueden sin manifiesta violencia impedir la ejecución de éstas Bulas, sin más título que un no quiero: ¿Que pretexto pueden alegar para esta resolución?; ninguno, porque si el provisto no tuviere las calidades necesarias, para ello la Santa Iglesia tiene sus Estatutos». R.A.H. Colección Salazar $y$ Castro, Sig. 9/135. 
un «cabildo secreto», al que solamente faltaron seis canónigos ${ }^{24}$. Una vez que les recordaron a todos los presentes el juramento de inviolabilidad de los temas que se trataban en aquellas reuniones, pasaron a comunicarles las actuaciones que se habían llevado a cabo, y sus resultados, para embarazar el ingreso del nuevo deán. Expusieron que la diputación de estatuto había ordenado al chantre que escribiera a su Santidad previniéndole de que había en su corte algunos pretendientes, naturales de León, que aspiraban a prebendas en esta santa iglesia y «que les contrariaba el estatuto de limpieza de sangre», por lo que «se dignase acomodarlos en otras iglesias». Estimaban que no habían logrado su objetivo porque en la carta no habían precisado el nombre de D. Antonio Castañón. También notificaron a los asistentes el envío de una segunda carta, dirigida al Papa, pidiéndole que hiciera un nuevo nombramiento de deán y que, a ser posible, los informara de los motivos que lo indujeron a designar a Castañón. La respuesta, que ya les había llegado, era que la decisión la había tomado en base a la recomendación del obispo y del ayuntamiento de la ciudad, que lo había calificado como de la primera nobleza, y esto mismo le habían dicho «otros príncipes eclesiásticos y seglares» que estaban interesados en su nombramiento. Ante esa situación, pedían a la comunidad que estuviera prevenida del estado en el que se encontraban las negociaciones y que, como «hay justas y legítimas causas», se resistiera a admitir la bula de D. Antonio hasta que no fueran apremiados y, cuando no les quedara otro remedio que aceptarlas, las remitieran a la diputación de estatuto, donde «discurrirían» la mejor forma de defender la postura que habían adoptado ${ }^{25}$. En este sentido, la propuesta fue la de nombrar como jueces calificadores para hacer la limpieza de sangre a personas de «mucha inteligencia y secreto... que pudieran resolver convenientemente y ejecutaran su parecer y resolución». Seleccionaron a siete miembros de la comunidad, los que consideraron que tenían mayor graduación «en letras, virtud, prudencia y autoridad».

Poco después el cabildo se vio obligado a aceptar la bula y en octubre de 1686 eligieron como jueces calificadores al chantre, que era e Lcdo. D. Lope de Trelles, y al lectoral, Dr. D. Juan Reyero. Tal nombramiento se hizo sin respetar lo contemplado en los estatutos de limpieza de sangre ${ }^{26}$ y las diligencia tampoco se iniciaron dentro

24. «Dijo el señor procurador se había juntado el cabildo para un negocio grave que requiere mucho secreto y que se necesita de renovar y ratificar el juramento que los señores tenían hecho de guardar los estatutos y loables costumbres en orden de pureza y limpieza de sangre...». Faltaron D. Juan Pulido, que estaba fuera de la ciudad, D. Marcos Guillén, D. Antonio Miranda, D. Manuel Flórez y D. Manuel Martínez, a causa de su enfermedad, y D. Baltasar Flórez, ocupado en «los asuntos del hospital». A.H.C.L. Leg. 10.009

25. A.H.C.L. Leg. 10.009

26. El 7 de julio de 1686 «Habiéndose juntado la diputación de estatuto para ver si había de seguir con los oficios respecto de no faltar si no es el de los señores jueces informantes ... se pasase al nombramiento de dichos jueces informantes en la forma ordinaria proponiendo antes de dicho nombramiento la gravedad de la pendencia de dicho deanato y autos capitulares que 
de los seis días que ordenaba aquellos. Se demoraron hasta el 3 de mayo de 1687, a pesar del mandato del obispo, del 7 de enero de 1687, para que no se retrasaran más. Ante el vendaval que se preveía, en las primeras páginas del libro de actas capitulares de aquel año, después de los juramentos, anotaron todos los acuerdos que se habían ido añadiendo a los estatutos que estaban en vigor. Concretamente, y por el orden que lo recogemos, dejaron anotaron que en el cabildo de 1671 habían acordado que ningún canónigo que hubiera sido vecino de una localidad que estuviera dentro de un perímetro de 10 leguas de la de procedencia del pretendiente y de sus padres podía ser informante, quedando excluidos los abuelos. El 14 de noviembre de 1645, añadieron que si algún informante había actuado por ignorancia en alguna prueba esa quedaría anulada, se repetiría y los nuevos gastos correrían a cuenta del anterior; y que si en la votación aparecía un haba negra los resultados no serían válidos, es decir, no se admitiría al candidato. El tercero era del 9 de agosto de 1670, y se establecía que ningún capitular que fuera pariente en grado conocido del pretendiente podía asistir a la lectura de las pruebas ni votarlas ${ }^{27}$.

El voluminoso expediente de D. Antonio, que se cerró el 4 de octubre de 1688, podemos dividirlo en dos bloques: el primero está dedicado a compulsar parte de las averiguaciones que se habían realizado en 1685 , enviadas al obispo para que intentara paralizar su nombramiento, y el segundo a recabar información complementaria en la ciudad y diferentes localidades de la provincia.

En la primera parte reprodujeron las respuestas vertidas por cinco capitulares ${ }^{28} \mathrm{a}$ tres de las, al menos, nueve preguntas a es habían hecho en su momento. Concretamente, de la sexta, séptima y novena. En la seis les interesaba saber si el pretendiente descendía por línea recta de un judío bautizado en 1495, llamado Abrahán Pardal, que había sido criado del prior y canónigo D. Pedro Ordás, en cuyo honor, por haber sido su padrino de bautismo, cambió el apellido. La siguiente cuestión se

sobre ella había y que era conveniente que no obstante hecho dicho nombramiento y quedarse en el arbitrio y facultad de cabildo cuando llegase el caso nombrar señor juez informante para las pruebas, así de los señores que estuviesen en cántaro como de los que hubiesen salido o no hubiesen entrado en él y que siendo necesario se jurase no contravenir esta proposición y parecer... y llegado dicho caso de haber de nombrar dicho juez informante la diputación pusieses los ojos en el señor que le pareciese más apropiado y que más altamente y con mayor reconocimiento e inteligencia lo pusiese... se halló que todos unánimes y conformes...». A.H.C.L. Leg. 10.010

27. A.H.C.L. Leg.10.011

28. Concretamente las de D. Antonio Miranda, D. Tirso Bayardo, D. Claudio Sanjurjo, D. Gaspar Pérez de Recalde y D. Placido Suarez de Zúñiga. Los tres primeros eran leoneses, dos de la capital y otro de una localidad cercana, el cuarto salamantino y el otro gallego. A todos los avalaba una larga trayectoria en el cabildo: los foráneos llevaban, en torno, a 40 años y los otros 32, 14 y 23, respectivamente. A.H.C.L. Expedientes de Limpieza. 
centraba en el padre del aspirante, D. Fernando Castañón Villafañe ${ }^{29}$, y el núcleo central de las indagaciones era saber si los problemas que le habían surgido en las pruebas para obtener el hábito de Alcántara, cuyo proceso llegó a prolongarse 12 años, derivaban de aquella ascendencia judía y si, finalmente, lo había conseguido gracias a poderosas influencias ${ }^{30}$. La novena hacía referencia a que se comprobara la certeza de que en la santa iglesia de León no había habido ningún canónigo de esa familia, a pesar de ser muy numerosa, ni tampoco pretendientes a una resigna, permuta o coadjutoría, debido a la resistencia que podía ejercer el cabildo.

Las respuestas fueron demoledoras. El primer testimonio que recogen, el de D. Antonio Miranda, comenzaba mencionando que siempre había oído que los Villafañe eran descendientes del «apellido infecto Ordás» por línea femenina. Del padre de D. Antonio decía que tenía un ascendiente curtidor, que efectivamente había tardado once o doce años en conseguir el hábito ${ }^{31}$ y se lo habían concedido gracias a la amistad que mantenía con el conde de Rebolledo, muy relacionado con el conde de Oropesa, presidente del Consejo de Ordenes. Añadía, que muestra de la mala fama de la familia era que no habían emparentado con otros linajes importantes de León y su entorno y, por ese rechazo, se casaban entre ellos o fuera de la ciudad. Confirmaba que, hasta entonces, ningún pariente pretendió entrar en el cabildo, «a pesar de ser acaudalados», y que incluso había estado mal visto entre los capitulares que el hermano primogénito del aspirante, D. Pedro Castañón, se hubiera casado con una hermana del canónigo D. Matías Acebedo. Completaba su declaración apuntando que un primo de D. Antonio había aspirado a una coadjutoría y la reacción del cabildo había sido, además de no facilitarle las cartas para obtener

29. El ascenso político y económico de la familia Villafañe en León había comenzado a mediados del siglo XIV, el primer regidor fue Pedro Núñez Villafañe, en 1391, y como tales, varios miembros de esta familia fueron representantes en Cortes de la ciudad de León. Entre las diferentes ramas que llevaban este apellido "parece segura la fuerte cohesión familiar». Los Villamizar, que veremos más adelante, obtuvieron el título de regidores, al menos en 1371, y mantuvieron una relación muy estrecha con los condes de Luna ALVAREZ, 1999: 280-343.

30. Sobre las manipulaciones de este tipo de investigaciones, puede consultarse CONTRERAS, 1995,105-124; SORIA, 2004: 21-55; FELICES, 2010: 229-252.

31. El hábito que solicitó fue el de Santiago, en 1644, entre los motivos que alegó para su concesión estaban el de haber servido al monarca, en 1632 y 1642, en Cataluña como capitán de 100 infantes durante seis meses; y la defensa en el ayuntamiento de la concesión de 300 ducados de plata al monarca y la prórroga de ese servicio. A todo ello, añade que su abuelo, Pedro Castañón, fue dos veces procurador en cortes por León y seis años corregidor de Ciudad Real. D. Fernando recibió el hábito de Alcántara en 1655. También en 1644 solicitaba D. García de Villamizar el mismo hábito, amparándose en los servicios prestados por su padre a la Corona. Tenía entonces 52 años, y uno de sus hermanos había sido canónigo en el cabildo leonés, D. Rodrigo de Villamizar, que entró en 1600. A.G.S. PTR Leg. 91, Docs. 358 y 362; A.H.N. C.O. Expedientillos, $\mathrm{n}^{\circ} 13$ y Caballeros de Alcántara, Exp. 303 y de Calatrava, Exp. 2.811. 
la bula papal, suplicar a los prebendados que no se comprometieran con ningún miembro de esa familia para tal fin.

D. Tirso Bayardo aún fue más incisivo y se explayó en sus respuestas. Comenzó haciendo alusión al judío Abrahán Pardal y a continuación relató tres conversaciones para reforzar su testimonio. Una la había mantenido con D. Marcelo de la Puente, mientras el cabildo estaba empantanado sus pretensiones al deanato, el cual, tras contarle Bayardo que D. Antonio Castañón aspiraba a esa dignidad, le había respondió «que no haría tal embarazo y, además, que su padre no se lo consentiría»" ${ }^{32}$, puesto que él había sido quien «ejerció negocio y buen despacho» para que le concedieran el hábito de Alcántara, emparentándolo con los Ordás de la montaña. La segunda fue con D. Manuel Canseco, que había sido prior en el convento de San Isidro, el cual le había dicho que, aunque un hermano de D. Antonio era canónigo en su convento, no admitiría a otro pariente tras ser conocedor del defecto que acarreaban. La tercera no concretaba con quien se había desarrollado, sí el contenido de la misma y era que lo había informado que el aspirante a deán, antes de ir a Roma, había pretendido ingresar en convento de San Marcos, donde no lo aceptaron por el defecto de sangre. Finalmente, amplió lo que ya había revelado el Sr. Miranda, que hacía dos años y medio ${ }^{33}$, más o menos, un primo de D. Antonio intentó entrar como coadjutor y el cabildo no consintió que se le diera el aval, incluso había amenazado al canónigo que lo respaldara con una multa de 400 ducados. Poco más añadió D. Claudio Sanjurjo, si bien aportó un nombre, Dña. María de Ordás, que sería crucial en el expediente que se hizo a partir de 1687. Indicaba que, a raíz de las indagaciones que se hicieron para la concesión del hábito a D. Fernando Castañón, la familia persuadió a aquella mujer para que negara el parentesco que los unía. D. Gaspar Pérez Recalde, quien decía llevar residiendo en la ciudad 50 años y más de tres décadas como canónigo, recordaba que al padre del pretendiente le habían costado mucho dinero, «y grandes empeños», los pleitos y las pruebas para alcanzar el hábito. La última declaración compulsada fue la de D. Placido Suárez de Zúñiga, atestiguaba que, «aunque nunca ha sido amigo de tener noticias de los linajes, mayormente de los de esta ciudad, por no haber tratado de emparentar con ellos», era sabedor de todo lo que habían testificado sus colegas.

Una vez que se compulsaron esas cinco declaraciones hicieron un descanso, coincidiendo con los oficios de la Semana Santa, y retomaron el expediente en abril 1687. Comenzaron y finalizaron las investigaciones en León, entre medias se desplazaron a todas aquellas localidades donde consideraron que podían obtener algún dato relevante. En total, hicieron a más de setenta entrevistas, sin computar el

32. El padre de D. Antonio había fallecido en 1678. A.H.C.L. Exp. 562.

33. Según Bayardo, el primo hacía dos años y medio, más o menos, que había pretendió la coadjutoría, algún otro lo retrotrae a cuatro años, pero casi todos coinciden en no decir el «nombre por no ser necesario». A.H.C.L. Exp. 562. 
que alguno fue interrogado dos veces ni a todos los escribanos y párrocos a los que recurrieron para solicitarles documentación que refrendara algunas informaciones.

En el segundo bloque del expediente volvieron a declarar, por pate del cabildo, Miranda, Recalde, Bayardo y Suárez Zúñiga, a los que se añadió el abad de San Guillermo y Colmenares. En esta ocasión respondían a las seis preguntas específicas del estatuto de limpieza. Miranda, tras señalar que ya había hecho una información secreta, pasó a responder el cuestionario. Afirmaba haber conocido a los padres de D. Antonio y ubicó la naturaleza de los apellidos: Castañón en Vegamián, Pardo en Astorga, Villafañe y Ordás en León. Añadía que en la ciudad había varias familias que llevaban el de Villafañe, como eran los señores del Ferral, los de la casa de Payana, el portero Mayor y algún otro, pero creía que el linaje del candidato solo tenía parentesco con el primero, y, de confirmarse, aquellos ya hacía muchos años que habían dejado de utilizar el Ordás. Conocía esa posible relación familiar por una capilla que habían tenido en el convento de San Francisco, ya derruida, donde conservaban una lápida en la que estaba inscrito: aquí yace «fulano Ordás, señor del Ferral y su mujer, cuyo apellido no se acuerda y fulano de Ordás, canónigo de Santiago, su hijo». Estimaba que esa declaración no resultaría difícil de comprobar consultado el archivo de los franciscanos, donde también podría hallarse el pleito que se originó a raíz del cierre de dicha capilla. Apuntaba que el apellido Ordás, que llevaba D. Antonio, provenía de «cierta mujer, que había venido de Vegamián, para casarse con un ascendiente del pretendiente, que bien podría llamarse Pedro Castañón». Se estaba refiriendo al cuarto abuelo de D. Antonio, que había sido Rodrigo Villafañe (Figura 1). Cuando retomaron el tema del hábito de D. Fernando Castañón, explicó que cuando un sobrino de aquel quiso recibir el de Santiago la familia había hablado con Dña. Ana Ordás, que ya hacía unos años que había muerto, para inducirla a que negara cualquier el parentesco entre ellos a cambio de una ayuda económica, que nunca le llegó. También decía saber que un primo del padre pretendiente, D. Álvaro Quirós, para «ponerse el hábito» recurrió a la ayuda del canónigo D. Pedro de Ordás, descendiente de los Ordás de Mata la Riba, y a la colaboración de un escribano «muy hábil»», al igual que habían hecho otros dos parientes, D. Francisco Ramírez y D. Ignacio Ramírez, este para obtener el hábito de Santiago. Engaño que, en su momento, le reprobaron al escribano porque podía perjudicar a los Ordás de la montaña, «cuya noble cabeza era el conde de Luna». Continuaba calificando a los abuelos de D. Antonio como cristianos limpios, pero con el lastre del apellido Ordás. También reprodujo una conversación que dijo haber mantenido con el Abad de San Isidro, D. Baltasar de Prado, en la que aquel había expresado que «era afortunado porque se había muerto el D. Juan de Castañón

34. No podemos comprobar la veracidad de la afirmación, pero los subterfugios para burlar con éxito estas pruebas venían de antiguo. SICROFF, 1985: 307 y ss.; si bien, la manipulación lo mismo podía favorecer que enturbiar un expediente. DOMINGUEZ, 1991:77; CONTRERAS, 1995: 105-124. 
(hermano de D. Antonio), porque yo estaba en volver a hacerle las pruebas porque cuando vine a la abadía cegué cuando lo vi dentro». Las informaciones vertidas por Recalde fueron muy similares a las de su colega, pero remontaba la historia de la familia a los primeros años del siglo XVI. Según él, en 1503 el prioste de la catedral había sido un Ordás, del que había una lápida enfrente de la contaduría, que habían borrado, y otra colocada en la iglesia de San Martín, a la que le habían dado la vuelta.

D. Tirso Bayardo, manifestó dudas sobre los posibles parentescos que pudieran existir entre los Villafañe que residían en León y desconocía la naturaleza de los Castañón. En esta nueva declaración recordaba a la persona que le había informado de las intenciones de D. Antonio de entrar en San Marcos. Se trataba del prior, que también le había contado que para calificar a un canónigo que se apellidaba Ordás habían utilizado "papeles falsos». Así mismo, mencionó otra charla que había mantenido con un canónigo de aquel mismo convento, el cual le refirió que había encontrado unos papeles, debajo de los portales de la Regla, en los que quedaba clara «la infección» del apellido «y que si los hubiera hecho públicos no había salido el hábito de Santiago del último de la familia que lo pidió». Añadía que ese canónigo «estaba hecho un perro» porque la familia le había ofrecido 200 doblones para que no los sacara a la luz y una vez que le concedieron el hábito no se los entregaron. D. Tirso, una vez más, relató los problemas de había tenido D. Fernando para calificarse y desarrolló la versión de 1685. Habló de unos papeles que se habían enviado a Madrid, no dice quien, con el objeto que no le concedieran el hábito, y como aquellos, tras perderse en el camino, la casualidad hizo que los encontrara D. Francisco de Prado, mayordomo del obispo fray Juan de Toledo. El prelado, después de leerlos, los quemó y declaró «que si hubieran llegado a Madrid no le hubieran dado el hábito». Ratificó que el priostazgo, tiempo atrás, había recaído en dos familias, una que se apellidaba Ordás y otra Palomino.

Por su parte, Suárez Zúñiga, ratificó todo lo que ya había referido anteriormente y no hizo ninguna aportación novedosa. El abad de San Guillermo, D. Fernando Colmenares, que había sido provisor del obispo fray Juan de Toledo, fue más benevolente y señaló el origen del problema que había tenido D. Fernando para recibir el hábito, que era uno de los puntos fuertes en los que se apoyaban todos los declarantes para anular las pretensiones de D. Antonio al deanato. Apuntó directamente a D. García de Villamizar ${ }^{35}$, que entonces residía en Madrid, el cual

35. A D. Blasco Marcelo Quiñones de la Vega, en sus pruebas para coadjutor, en 1661, también acusado de tener ascendencia judía y miembro de una linajuda familia leonesa, como era la casa de Alcedo cuyos orígenes estuvieron en el condado de Luna, varios testigos coincidieron en señalar a la familia Villamizar, ya fuera a D. Antonio o a D. García, ambos regidores leoneses, como enemigos e incitadores de atribuirle ese origen. Precisamente, en 1659 habían encarcelado a tres regidores, uno de ellos, un hijo de D. García Villamizar, por la muerte de D. Antonio Rubín de Celis. Si bien, los enconamientos venían de muy atrás, pues en 1607 la afectada fue esta familia, cuando asesinaron a D. Pedro de Villamizar, en la plaza de la Regla, y 
«pidió unos papeles contra D. Fernando, pero no sabe a quién los enviaba a pedir». Atribuyó a los Castañón la condición de cristianos viejos, reforzándola con el hecho de haber superado las pruebas D. Juan Castañón, para ingresar en el convento de San Isidro, y recientemente D. Isidro de Llanos ${ }^{36}$, pariente de D. Antonio, para el de San Marcos — «donde las pruebas eran muy rigurosas»-. También explicó que cuando aquel recibió tal concesión, el cabildo, por medio de su diputación y del procurador general, pidió al obispo que remitiera unos escritos a su Santidad para que se no tuviera efecto el nombramiento. No hizo ninguna alusión al apellido Ordás.

Una vez que terminaron de declarar los canónigos, los examinadores pidieron que se verificara todo lo que habían manifestado, la ubicación e inscripción de la lapidas, los priostrazgos ${ }^{37}$ o que se buscara en los listados de judíos a Abrahán Pardal. Las primeras las encontraron, así como algunos Ordás en los libros del archivo, pero lo más importante: no hallaron ninguno que pudiera ser padrino de aquel judío, ni tampoco el apellido Pardal estaba en las relaciones elaboradas antes de la expulsión, que se conservaban.

Hechas todas aquellas gestiones volvieron a retomar los interrogatorios, pero ahora se decantaron por profesionales, regidores y vecinos de la ciudad que fueran buenos conocedoras de las familias leonesas. Las relaciones de Dña. Ana Ordás con la familia del candidato y el problema que había tendido D. Fernando Castañón para recibir el hábito fueron los ejes en torno a los que gravitaron las indagaciones. Respecto a la primera cuestión, los recuerdos que tenían de aquella mujer o lo que habían oído sobre ella, apenas consiguieron reunir información. La mayor parte de los inquiridos solamente sabía que había sido hija de un regidor, no les constaba que tuviera parentesco con el pretendiente o no eran sabedores de que tuviera «mala fama». Por su parte, Domingo González, vecino de León, decía que conoció a varias personas en la ciudad que llevaban el apellido Ordás, desde un panadero hasta dos canónigos, uno en el cabildo catedralicio y otro en el de San Marcos, ambos naturales

se acusó a varios regidores de la ciudad. A.H.C.L. Exp. nº 448, Archivo Histórico Municipal de León (A.H.M.L.) C.54 y Archivo Histórico Provincial de León (A.H.P.L.) C. 268.

36. Según los expedientes, D. Isidro era de Valderas y entró en San Marcos en 1689. Era hijo de D. Isidoro de Llanos y Dña. María Quirós. (Archivo Histórico Diocesano de León) A.H.D.L. Toma de Hábitos del Convento de San Marcos.

37. En una de las ubicadas en la catedral se leía: «aquí yace el honrado García Ordás prioste, que fue de esta Santa Iglesia», y estaba fechada el día 8 de noviembre de1408; y en otra «aquí yace D. Luis de Ordás Ramírez, prioste que fue de esta Santa Iglesia y regidor de esta ciudad y Dña. Luisa de Ocampo, su mujer», acompañados de un hijo de ambos Gaspar Ramírez y la fecha de fallecimiento de los tres, 8 de diciembre de 1616, 7 de julio de 1615 y 25 de abril de 1619, respectivamente. Había otras dos piedras más con el apellido Ramírez. Volvieron sobre los libros, para ver si se correspondían aquellas personas con las ocupaciones y, efectivamente, ambos habían sido priostes, así como otros con el mismo apellido, en los primeros años del siglo XVI y en el último tercio de la misma centuria. 
de una localidad cercana a Boñar, así como a Dña. Ana, a cuyo padre lo tenían por «infesto» porque cuando era muchacho decían «viene el judiyuelo», y había oído comentar que «se trataban de parientes con D. Andrés y D. Fernando Castañón». Respecto al tema del hábito de D. Fernando, el receptor de la audiencia apuntaba, de nuevo, a D. García de Villamizar como instigador de todo el problema. El cual radicaba, según unos, en que D. García, intencionadamente, había querido entroncarlo con aquella mujer y otros aclaraban que era fruto de una confusión, puesto que había dos familias Ordás, una de León, que se tenía por descendiente de judíos, y otra, «sin mácula», procedente de la montaña. Y precisamente ese había sido el motivo por el que no admitieron, en su momento, como coadjutor al pariente de D. Antonio, D. Domingo de Villafañe, el cual sí superó las pruebas que le hicieron para inquisidor. D. Diego Girón y Fray Baltasar Prado, añadían que ese mismo apellido lo llevaban D. Alvaro Quirós y D. Juan de Llanos $^{38}$, parientes directos de D. Fernando y que ambos habían sido calificados en Mata la Riba para el obtener el hábito de caballería. Solo el regidor D. José Llamazares Reyero, se mostró más contundente, pues dijo que el «el hábito lo consiguió porque logró ocultar el apellido Ordás». Prácticamente todos de examinados coincidieron en que el apellido Castañón era originario de Vegamián.

Finalizadas aquellas intervenciones volvieron a retomar las cuestiones burocráticas, pidiendo a escribanos, inquisidores y párrocos que hicieran un rastreo de todas las partidas y escrituras que pudieran aportar relacionadas con la familia. Considerando que no eran suficientes las presentadas ${ }^{39}$, solicitaron los testamentos de D. Andrés, D. Pedro y D. Hernando Castañón, Dña. Antonia y D. Benito Castrillo, Dña. Elena Santisteban y los otros ascendientes lejanos de D. Antonio ${ }^{40}$.

38. El expediente del primero se hizo en 1647 y el otro en 1666. A.H.N. C.O. Caballeros de Santiago, Exps.6818 y 4734.

39. Entre ellas estaban las partidas de bautismo de D. Antonio Castañón, D. Fernando y D. Benito de Castrillo, hijo de Pedro del Castrillo, notario. También las de defunción de Dña. Elena Santisteban, esposa de D. Benito de Castrillo o la de D. Andrés Castañón. Junto a estas se entregaron otras de parientes más alejados, apellidados Villafañe y Castañón.

40. Poco tiempo después presentaron varios testamentos: el de D. Rodrigo de Villafañe, hecho en León el 24 de diciembre de 1543; el de su esposa, Dña. Beatriz Ordás, del 9 de marzo de 1579, una de cuyas cláusulas decía que había casado a su hija, Dña. María de Villafañe con D. Fernán González Castañón, primos en cuarto grado, y tenía pagada la dote. Lo primero que hicieron fue ir a pedir la dispensa de aquellos a D. Antonio, que la aportó, pero tuvieron dudas de su autenticidad y mandaron que se buscara en el archivo episcopal por los años 1533 o 1534. No encontraron registros de aquellas fechas y un «señor» dijo que hacía unos años había visto a un boticario rompiendo hojas, «porque lo sentenciado no era de provecho». Otros testamentos exhibidos fueron los de D. Hernando González de Castañón, redactado el 15 de octubre de1568 y abierto en 1572, quien pedía ser enterrado en el convento de Santo Domingo y dejaba como heredero a su hijo único, D. Pedro, regidor de León; el de Dña. Clara Gutiérrez, fechado en 1594; el de D. Pedro Castañón, de 1611, que pedía que su cuerpo se depositara en 
Las principales objeciones para continuar en ese momento con las averiguaciones fueron que no encontraban una dispensa matrimonial de la familia ni las dotaciones que había dejado D. Fernán González Castañón en el convento de Santo Domingo. Sí, en cambio, las sepulturas de aquel y su esposa, en la capilla de Nuestra Señora de la Concepción del convento de San Isidro ${ }^{41}$, y la justificación realizada por D. Pedro Castañón cuando efectuó el trasladado de sus huesos desde San Claudio.

Iniciadas de nuevo las gestiones, se dirigieron al convento de San Marcos para entrevistar a D. Miguel de Prado. Ratificó la declaración que poco antes había realizado el leonés Domingo González, que, efectivamente, habían existido dos canónigos apellidados Ordás: D. Pedro, en la iglesia catedral, y D. Simón, que había llegado a ser prior en San Marcos, si bien desconocía si tenían parentesco con D. Fernando Castañón. Negó, o al menos no recordaba, las conversaciones que D. Tirso Bayardo dijo haber tenido con él, sobre las pretensiones de D. Antonio de ingresar en aquel convento y la falsificación de papeles.

Como los testimonios que había recopilado hasta el momento no avalaban los realizados por los canónigos, en 1685, decidieron entrevistar a más personas de la ciudad. El primero fue el regidor D. Francisco Lorenzana. Este hombre, aparte de desconocer si existía consanguineidad entre los Castañón y el señor del Ferral, aseguraba que cuando murió D. Andrés Castañón su viuda, Dña. Antonia de Castrillo, se casó con el también regidor D. Francisco Palomino Lorenzana y cuando falleció había comparado su regimiento D. Fernando, padre del pretendiente ${ }^{42}$. Conocía a otros Castañón, primos de D. Antonio, uno de ellos regidor en la ciudad, y a varios Ordás, pero no tenía noticia de que fuera un apellido infecto, ni tampoco que tuvieran relación con Dña. Ana. Respecto a las pruebas de D. Fernando, afirmaba que se habían hecho dos veces, con distintos informantes, y que las segundas estuvieron «detenidas hasta que salió el hábito para D. Juan de Llanos». En este sentido, ratificó lo aportado por el canónigo D. Antonio Miranda, en cuanto a la ayuda que les prestó el conde de Rebolledo. También este regidor señaló a D. García de Villamizar como

el monasterio de San Claudio, concretamente en la capilla que tenían en el claustro, entre la de los condes de Luna, la de la casa de D. Antonio de Quiñones y la de los señores de la casa de Omaña. Junto a estos testamentos aportaron numerosas escrituras de compra y venta, foros o trueques, todos del XVI, donde aparecían Villafañes, pero no explicaban las relaciones de parentesco que tenían con el candidato.

41. Estas aún se conservan. En una hornacina reposan los restos de D. Juan Castañón, D. Fernán González Castañón y Dña. María Villafañe. Por su parte, los de D. Fernando Castañón Villafañe y Dña. Ana Pardo lo hacen bajo el pavimento, cubiertos con una losa en la que aparecen sus nombres y a los pies de la misma el blasón familiar, en el que se representan los apellidos Castañón y Villafañe. El cuartel de este último es el mismo que tenía el escudo de la casa palacio de los Villafañe, construida en el siglo XVII. CIMADEVILLA, 2001: 179 y 541.

42. Otros testigos señalaron que había sido D. Antonio Castañón Villafañe, como curador de su sobrino, D. Fernando Castañón, quien le había comprado ese regimiento en1638. 
causante de todos los problemas, pero suavizaba la acusación asegurando que era un caballero muy calificado y «en la ciudad se decía que no pasaba nada que fuera contra la verdad de las noticias que él tenía». Prácticamente las mimas aportaciones hicieron el resto de los entrevistados ${ }^{43}$.

Un testimonio especialmente buscado fue el de Dña. Rosenda Manrique, oriunda de Galicia, que «desde muy pequeña se crio con Dña. Ana Ordás». Recordaba que le habían tomado declaración exhaustiva cuando se habían hecho las pruebas de D. Fernando y que Dña. Ana «estaba quejosa y sentida» con él, pero desconocía el motivo, como también si tenían algún vínculo familiar entre ellos. Lo único que sabía con certeza era que Dña. Ana había sido hija del regidor D. Diego de Ordás y Valencia y que tenía un hermano, D. Luis de Ordás Valencia, que habían tenido que empeñar el regimiento que heredó de su padre.

La duda no resuelta de la relación entre las diferentes casas Villafañe que había en la ciudad de León, la disipó D. José Villafañe de la Payana. Explicó que, según había oído a su padre y a D. García de Villamizar, eran todos descendientes del mismo tronco: los Castañón por «hembra» y ellos por varón, lo que contradecía a Miranda, que había dicho que los Villafañe lo eran por línea femenina. D. José llegó a conocer a Dña. Ana de Ordás, pero no sabía que tuvieran ningún tipo de relación consanguínea con ella.

Una vez recogidos todos estos testimonios y el amplio abanico de escrituras y partidas sacramentales, los calificadores enviaron todo a la diputación del cabildo, el 27 de julio de 1687, que consideró que aún no tenía material suficiente para tomar una decisión. Los dos inconvenientes que ponían en ese momento eran que no habían encontraron la dispensa matrimonial de D. Fernán González de Castañón ni su título de regidor.

En el mes de agosto, los informantes salieron a las localidades de origen de los ascendientes de D. Antonio. Comenzaron por Vegamián, donde la declaración del primer testigo, con pocas variaciones, la repitieron los ocho primeros examinados. Alonso de Caso dijo que había conocido a los padres del aspirante a deán cuando iban al pueblo a cobrar las alcabalas, que allí percibían y en la jurisdicción de Redipollos; también sabía que D. Fernando tenía una relación de parentesco con los Castañón de aquella villa, donde se hospedaba cuando la visitaba, si bien los locales en ese momento utilizaban el apellido Díez Castañón. Un miembro de

43. Según Diego Robles, todos los problemas del padre con el hábito habían surgido al confundir una casa ubicada en la plazuela de la Plegaria con otra en la calle Revilla, que había sido de «fulano de Villagómez», barbero y cirujano. Ese hombre había sido procesado en Valladolid por el tribunal inquisitorial y, posteriormente, liberado. Su casa la compró el abuelo o bisabuelo, no recordaba, del pretendiente y al no aparecer la escritura de venta surgió la confusión, que quedó aclarada cuando aquella pudo aportarse. 
esta familia afirmó la existencia de tales vínculos y añadió que D. García de Villamizar había hablado con D. Fernando para pedirle perdón por los trastornos que le había ocasionado con motivo del hábito y que, posteriormente había realizado una nueva declaración que remitió al Consejo de Ordenes. Reyero y el Chantre encargaron que se buscara a los Castañón en todos los libros sacramentales y en los padrones, así como los bienes raíces que pudieran tener en la zona. Entre tanto, se desplazaron a Campillo, donde ninguno de los seis sondeados aportó nada nuevo. De regreso a Vegamián inquirieron a Dña. María Ordás, cuya declaración fue muy esclarecedora. Aseguraba que aquel parentesco, tal y como había oído relatar a su padre y a otros parientes, se remontaban a Beatriz de Ordás ${ }^{44}$, que se había casado en León con Rodrigo Villafañe, de quienes descendían D. Fernando y D. Antonio. A su vez, Beatriz era hermana de D. Bernardo Ordás Villafañe, que había sido tesorero de la santa iglesia, por lo que los calificadores lo primero que le pidieron fue que lo justificara documentalmente. Se encontraron en Otero dos escrituras de donación, una hecha por Pedro de Ordás, vecino de aquel lugar, a su sobrina María Villafañe, cuando se casó con D. Fernán, que incluía un prado, lo que les costara la dispensa matrimonial y 80.000 maravedíes que habían «quedado mandados por los padres de María Villafañe», en 1532; y la otra, fechada en diciembre de mismo año, realizada por D. Bernardo Ordás, tesorero, a favor de los mismos. Ante tales evidencias los informantes, aún no conformes, pidieron el testamento del padre de Beatriz y todos los padrones que se pudieran encontrar. Regresaron a Valdepiélago, donde interrogaron a otras dos personas, que no contradijeron ninguna de las declaraciones anteriores.

Tras recabar la información en las localidades montañesas se dirigieron a Cembranos, dónde algún testigo había señalado que estaba el origen del apellido Castrillo, que correspondía a la abuela paterna de D. Antonio. Tras entrevistar a casi a una docena de personas no averiguaron nada concreto.

44. En las pruebas, no sabemos si en las primeras o en las segundas, de D. Fernando Castañón para el hábito de Alcántara, a Beatriz de Ordás, casada con D. Rodrigo Villafañe - que tenía bienes en Vegamián y en el valle de Boñar-, le adjudicaron como lugar de procedencia Santa María de Ordás, donde sus antecesores tenían la casa solariega. El parentesco radicaba en que Beatriz de Ordás, era hija de García de Ordás y de Violante García, y nieta de «Alonso de Ordás y Ana Díez, naturales de Santa María de Ordás donde está la casa solariega del apellido Ordases». SERRANO, 1967: 628. 
Fig.1 Genealogía de los Castañón Villafañe

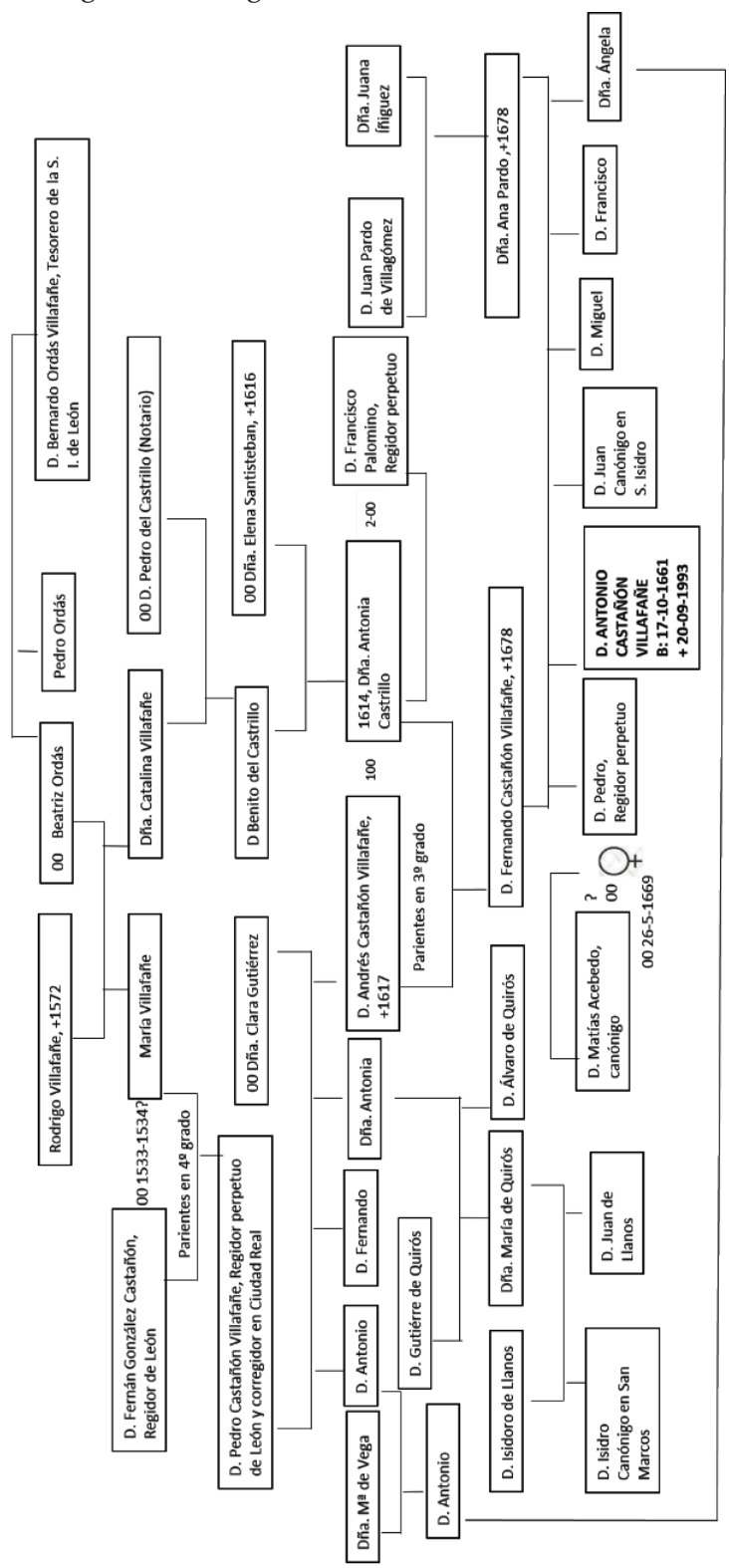

Elaborada a partir del Expediente de D. Antonio Castañón y escrituras notariales. A.H.C.L. Exp.562 y A.H.P.L. Protocolos.

Ediciones Universidad de Salamanca / @@@ Stud. his., H. ${ }^{a}$ mod., 41, n. 2 (2019), pp. 71-101 
A la ciudad de Astorga fueron a examinar el apellido Pardo. El primer informador testificó que se trataba de una familia muy bien considerada, que también solía utilizaban el apellido del Cerro y que un hermano de la madre de D. Antonio, D. Pedro Pardo, había sido maestreescuela en el cabildo de Astorga. Según el siguiente interrogado, el padre de Dña. Ana, D. Juan Pardo, había sido «criado» de los marqueses de Astorga, que lo había nombrado corregidor de Villamañán y Villazala, y añadía otro apellido más a la familia, el Cela. Aunque, en realidad, éste recaía en un medio hermano de D. Juan Pardo, que había sido canónigo en Astorga. Los otros cinco testigos no aportaron ninguna novedad, salvo uno que dijo que tenían algún parentesco con los Villagómez ${ }^{45}$, lo que les llevó a recabar información en Castroverde. La única averiguación que lograron en esa localidad fue que «un criado» del marqués de Astorga se casó en aquella ciudad con una mujer que se apellidaba así, pero desconocían la relación que pudieran tener con Dña. Ana Pardo $^{46}$. También se desplazaron a Villagarcía y otras localidades próximas para continuar la investigación de los Pardo, sin lograr ningún avance.

De vuelta en León, pidieron que se localizaran varios testamentos de los ancestros del candidato a deán y el título de regidor de Fernán González Castañón, y volvieron a convocar a más testigos. Uno de ellos fue D. Diego Villafañe Tapia y Quiñones, regidor de la ciudad y señor del Ferral, quien había oído hablar de Dña. Ana de Ordás, pero nunca había sabido que tuvieran parentesco con ella. Según sus informaciones, el Ordás que llevaban les tocaba por Beatriz de Ordás y todos los Villafañe procedían del mismo tronco ${ }^{47}$. De hecho, en León había una cofradía, la de los Villafañe, en la que para entrar se hacían las correspondientes pruebas de nobleza, limpieza de sangre, se exigía ser hijo legítimo y originario de la ciudad ${ }^{48}$, y a la mima pertenecía D. Francisco Castañón Villafañe, tío carnal de D. Fernando. En otra ronda de declaraciones, D. Manuel Canseco, canónigo en San Isidro, ratificó la existencia de dicha cofradía y, de nuevo, la declaración de D. Tirso Bayardo se

45. Por otros expedientes, sabemos que Dña. Ana de pardo era sobrina de D. Pedro Villagómez y Pardo, arzobispo de Lima y prima de D. Francisco Villagómez y Pardo, corregidor de Riobamba en Indias.

46. En la parroquia de San Julián de Astorga recopilaron algunas partidas de bautismo de la familia: la de D. Eugenio, el medio hermano de D. Juan; la de Dña. Ana, fechada el 29 de octubre de 1631, y sus padres Dña. Ángela -16 de marzo de $1603-$ y D. Juan de Pardo -3 de abril de 1605-.

47. En otros expedientes realizados para la toma de hábitos de miembros de la familia Villafañe, declararon que todas las familias de ese apellido procedían del mismo tronco y que desde el siglo XIV residían en León, enfrente de la parroquia de San Marcelo. SERRANO, 1967: 627.

48. Esta cofradía se constituyó a comienzos del siglo XIV. Tenía la sede en la parroquia de San Marcelo. SERRANO, 1967: 626; A.H.P.L. C. 216. 
puso en entredicho, pues no recordaba que le hubiera hecho ningún comentario de D. Juan Castañón, canónigo en san Isidro.

Los informantes volvieron a insistir en que se revisara la documentación de las casas que habían ocupado los judíos en León que pagaban fuero a la santa iglesia y los padrones, pero siguieron sin encontrar rastro alguno de Abrahán Pardal. A continuación, exhibieron en el cabildo las donaciones y testamentos que habían localizado en la montaña y su respuesta fue que se buscara en el archivo a D. Bernardo Ordás. Efectivamente lo encontraron, había ocupado el cargo de tesorero, dejó fundada una obra pía para casa huérfanas y realizó «algunas cesiones» en Roma, en $1548^{49}$.

Hasta el momento, no tenían nada en firme para sustentar esa «mácula» que decían pesaba sobre la familia Castañón, por lo que, volvieron a explorar a los canónigos -D. Gaspar Arcentales, D. Antonio Álvarez de Miranda y D. Gonzalo Pérez Recalde-, que ratificaron las declaraciones anteriores, y a otras personas. Una de ellas fue Fray Vitorio Canseco, benedictino en San Claudio, quien decía haber escuchado a Dña. Ana Ordás que D. Fernando era sobrino suyo por el apellido Ordás, quejarse de que no la asistía y de que le había usurpado el oficio de regidor que le correspondía a su hermano. Contaba, además, una reyerta que habían tenido D. Antonio y un hermano de D. Ignacio Ramírez Ordás, porque el primero llamó judío al otro en público, a lo que le contestó que si él era judío lo eran los dos porque eran primos. Por su parte, Francisca González Acebedo, que había sido vecina de Dña. Ana Ordás, primero revelaba que había oído a aquella que algunos caballeros y regidores de la ciudad eran parientes suyos, pero nunca había dicho sus nombres, y que no sabía que le hubieran ofrecido dinero por negar que tuviera relación con D. Fernando Castañón y D. Juan de Llanos; y, a continuación, señalaba que, precisamente, era de aquellos de los que se quejaba. Otros declarantes fueron D. Juan de las Calzas y Castrillo, cura de Vilecha, el regidor D. Diego de Quiñones o Dña. Antonia de Quiñones, viuda del marques de Lorenzana, según la cual, D. Isidro de Villagómez, canónigo en San Marcos, era nieto de una prima hermana de D. Fernando, Dña. María de Quirós.

Fueron apareciendo nuevas escrituras y entre ellas estaba la copia del despacho de regidor a Fernán González de Castañón, fechado en 1558, compulsada en Simancas. No conformes con todo lo reunido, solicitaron, entre otras cosas, que se examinara a todas las personas citadas por los testigos, que aportaran papeles de todo lo declarado por aquellos, que se buscara diversa documentación de los ascendientes de Rodrigo Villafañe. Lo único que encontraron, de forma inmediata, fue el inventario de Rodrigo de Villafañe y su mujer, Beatriz de Ordás, realizado en 1544.

49. En al A.H.P.L. se conserva un testamento del Dr. D. Bernardo de Ordás, canónigo y tesorero de la Santa Iglesia de León, elaborado en 1546, bien podría tratarse del mismo, pues cita como hermano a Pedro de Ordás. 
Poco después el cabildo decidió hacer la votación de las pruebas, el 4 de octubre de 1688 , en la que salieron más habas negras que blancas, lo que implicaba rechazar a D. Antonio Castañón para ocupar la dignidad. El mes anterior, habían pedido, en dos ocasiones, al obispo que participara en la votación y en ambas declinó la petición ${ }^{50}$.

Mientras duraron las pruebas, D. Antonio apremiaba al cabildo para finalizarlas y este a los informantes ${ }^{51}$. En febrero de 1688, Reyero había presentado los avances que llevaban hechos para que el cabildo presentara los reparos que estimaran oportunos. Aquellos se leyeron en cinco reuniones capitulares consecutivas, tras las que hubo un receso, con motivo de la Semana Santa, y a la vuelta les dedicaron otros nueve días, ordenando que, mientras tanto, ningún prebendado pudiera ausentarse. El 19 de mayo hicieron la primera votación, para acordar si las daban por finalizadas, y determinaron que debían continuarse, pero los achaques de los informantes les impedían salir de la ciudad y ningún otro capitular quería sustituirlos. En junio les llegó un notificación de apremio, emitida por el provisor, al que respondieron que no tenía autorización sobre el cabildo en esa materia, y en julio otra del nuncio ${ }^{52}$, al que había recurrido D. Antonio ${ }^{53}$. No obstante, y como ya hemos señalado, hasta octubre no tuvo lugar la votación ${ }^{54}$.

50. El 1 de septiembre de 1688, la diputación del cabildo envió a D. Antonio de Quiñones y al doctoral "para que vieran al obispo y le informaran del contenido de las pruebas y le suplicasen se sirviese de asistir a juzgarlas y su ilustrísima se excusó». Tres días después, obtuvieron la misma respuesta, "para desconsuelo del cabildo el obispo se excusó», y mandaron que lo visitara D. Antonio Miranda y D. Juan Reyero, quienes tampoco tuvieron éxito. A.H.C.L. Leg. 10.012.

51. El 7 de noviembre de 1687, el cabildo encargó a «los señores de la diputación» que se dieran prisa en concluir las pruebas de D. Antonio de Castañón y volvieron a hacerlo el 19 de enero de 1688. El 30 fue D. Antonio quien les suplicaba «que dentro de breve termino el señor informante concluyese sus pruebas por el grave agravio y gastos que se le han seguido y siguen». Reiteró esa petición pocos días después. A.H.C.L. Leg. 10011.

52. Sobre la evolución y competencias de la nunciatura consultar VÁZQUEZ, 2000: 507-538; PUENTE, 2002:19.

53. A.H.C.L. Leg. 10011

54. Todo ese proceso no estuvo exento de presiones y tensiones. En julio de 1687 se expuso en el cabildo que «fuera de hora y al tiempo que la gente estaba recogida en su casa por el calor», D. Diego Villafañe había entrado en casa de Reyero amenazándolo con que lo «había de matar a puñadas». El cabildo convocó al intimidado para que expusiera los hechos, pero no quiso decir nada «para no ir en perjuicio del informado». En otro documento nos dan más noticias de la amenaza sufrida. Entró en casa del Reyero D. Diego Ordás Villafañe, presbítero, caballero de Santiago y pariente del aspirante, se dirigió a su cuarto, donde sacó una «fala y le dijo qué cómo se metía con su calidad, que tratase de disponer corriesen y saliesen las pruebas del pretendiente porque si no a él y a D. Juan Palacios, canónigo de dicha Santa Iglesia, que asistía a ellas (como secretario), les había de matar a puñadas». A.H.D.L. M. 57. A través de las actas capitulares, del 20 de junio de 1691, conocemos el castigo impuesto por el Consejo de Ordenes a Villafañe, que fue el destierro, no sabemos por cuanto tiempo ni distancia. Pero no 


\section{D. ANTONIO CASTAÑÓN, DEÁN DEL CABILDO LEONES}

D. Antonio Castañón, en cuanto tuvo conocimiento de los resultados del escrutinio, apeló al nuncio ${ }^{55}$ y se inició un pleito cargado de tensiones ${ }^{56}$. Ese lo podemos rastrear en las diferentes cartas y protestas realizadas por el doctoral D. Blas Gutiérrez Campo, D. Agustín Estefanía, cada uno seguido por sus intereses, el sumario que se elaboró en el Consejo de Castilla, el informe encargado al arcediano de Tineo o las representaciones hechas ante el monarca por la «Santa Iglesia de Toledo». Todo ello complementado por las actas capitulares, que son muy escuetas a la hora de ofrecer datos sobre toda aquella cadena de acontecimientos.

Siguiendo la representación del cabildo de Toledo ${ }^{57}$, que abarca desde los acontecimientos de septiembre de 1689 hasta los autos de 1691, tras las investigaciones pertinentes de la genealogía de D. Antonio y su reprobación por parte del cabildo, aquel apeló al nuncio, el cardenal Durazzo, quien revocó el acuerdo capitular. Fue entonces, cuando en nombre de D. Antonio se convocó a los prebendados para que le dieran la posesión de la canonjía y deanato, pero aquellos se excusaron alegando carecer de competencias para tal menester. De nuevo, el aspirante recurrió a la nunciatura, que le encargó al abad de San Claudio dirigir el proceso para la toma de posesión. El cabildo, receloso de la actuación del nuncio, obtuvo un Breve Cameral,

debió de ser inmediato pues, en la misma reunión, se dejó constancia de que se prohibía a los capitulares hablar con él, pero que los señores Turrado y Martínez Malo, «en odio al acuerdo capitular no lo respetaron", por lo que se pedía un castigo para ellos. Fueron multados en 10 ducados. A.H.C.L. 10.013

55. Antes solicitó que se volvieran a votar sus pruebas por haber «votado algunos señores que fueron testigos en la información», le respondieron que, como estaban terminadas y el auto y sentencia apelados por su parte y por el cabildo, quedaba «extinguida su jurisdicción y no había lugar a lo que pedía». El 1 de diciembre de 1688 presentó en el cabildo un auto, despachado por el nuncio, para que se le remitiesen las pruebas originales. A.H.C.L. 10.012.

56. En agosto de 1689, el cabildo ya temía las consecuencias que pudieran derivar de todo ello y el día 23, «El procurador juntó el cabildo para discurrir que se había de hacer en la defensa del pleito de las pruebas de D. Antonio en caso de que la sentencia fuera contraria a la pronunciada por el cabildo y prevenir los lances y operaciones que se debían ejecutar respecto de haberse hecho tan público un pleito y habiendo conferido tanto alcance... acordaron que dándose sentencia contra el cabildo se siga con todas las fuerzas legales en atención a estar así prevenido por dichos estatutos y practicado en casos semejantes y en fuerza del juramento especial que cada señor prebendado hace de defenderlos». Siete días después, también el procurador, expuso que «tenía noticias, aún por voces vagas, que el nuncio había revocado la sentencia dada por el cabildo en las pruebas de D. Antonio». Acordaron «extender un poder de apelación de cualquier sentencia del nuncio y censuras que hubiera promulgado a su Santidad y demás señores que tuvieran facultad para ello y protestaban el real auxilio de la fuerza en caso necesario en el pleito de pruebas». A.H. C., Leg. 10.012.

57. Hay varias versiones, más o menos amplias, pero con el mismo relato. Hemos utilizado la más completa. A.H.D.L. Ms. 57; R.A.H. Sig. 9/135; R.A.H. Colección Salazar y Castro, 9/35. 
del papa Inocencio XI, para que, en grado de apelación, interviniera un juez sinodal de León, Santiago u Oviedo. Se prescindió de los de León, porque eran prebendados y podía actuar con arbitrariedad, y de los de Santiago, por la distancia. Se nombró al asturiano Dr. D. Antonio Llanes Campomanes, arcediano de Tineo y catedrático de vísperas de la universidad ovetense.

El 19 de septiembre de 1689, el abad de San Claudio, Fray Juan Moniz, pidió al procurador general del cabildo que lo convocara en un plazo de dos horas para que se efectuara la toma de posesión, pero, como ya era tarde y estaba disuelto el coro, lo dejaron para el día siguiente, a las ocho de la mañana. El día 20, continuaban relatando, a las siete de la mañana en la plaza de la iglesia catedral, su entorno e, incluso, el interior, había «más de tres mil personas, de todas clases y oficios» ${ }^{58}$, «convocados públicamente y con intenciones poco pacíficas», entre ellas el Alcalde Mayor y sus ministros. Ante esa expectación, el abad entró en el claustro con el notario, D. Antonio y «un tumulto de personas» y cuando llegaron a la sala capitular encontraron la puerta cerrada, circunstancia que estuvo motivada por adelantarse a la hora fijada para la reunión. Ante esa situación, el procurador, por ser leonés D. Antonio y «temer un escándalo apasionado», informó al abad de una nota inhibitoria del juez apostólico de Oviedo, para paralizar el proceso. Efectivamente, continua el texto relatando, los malos presagios se cumplieron, «el abad mandó echar abajo la puerta y alentó el tumulto», y acompañado por otros religiosos de su orden y seis prebendados, de los 51 que «residían actualmente», le dieron la posesión del deanato a D. Antonio, con las consiguientes protestas del resto de los capitulares. Los tumultos continuaron en los días siguientes, por lo que el cabildo solicitó la intervención del Alcalde Mayor para sofocarlos. Por su parte, el juez de la nunciatura, informado de esos desordenes, en enero de 1690, por uno canónigo posicionado del lado de Castañón, ordenó que se arrestara a 34 capitulares contrarios al deán, les embargaran los bienes, los privaran de voz y voto en el cabildo y fueran excomulgarlos. Los agraviados pusieron un recurso ante la nunciatura, que, en una en segunda sentencia, de noviembre de 1691, les rebajó las condenas. No satisfechos con el segundo fallo volvieron a apelar. El veredicto, de diciembre de 1691, fue algo más moderado y personalizaba las penas. También recurrieron al monarca, solicitándole protección y ayuda para la santa iglesia de León, sustentando la demanda en que tenía una doble obligación para intervenir, por patronato y como canónigo que era con voz y voto ${ }^{59}$.

58. La cifra nos resulta un tanto exagerada, puesto que la ciudad, que tenía en 1631, 1.268 vecinos, en aquellas fechas estaba en fase de retroceso, consecuencia de las dificultades agrarias que se iniciaron en la década de los setenta y que, agravadas con enfermedades, continuaron hasta la de los noventa. GARCÍA, 1999: 192; PÉREZ, 2009:61.

59. En el cabildo leonés había dos canonjías seglares, una pertenecía al rey y otra al marqués de Astorga. 
Pero antes de que ocurrieran todos aquellos desagradables acontecimientos, en agosto de 1689, el cabildo ya había acudido al Consejo de Castilla ${ }^{60}$. Le extendieron un poder a D. José de Bustamante para que compareciera ante los jueces sinodales y apelara la sentencia del nuncio, en la que revocaba la decisión del cabildo, y se privara a Fray Juan Moniz de intervenir en el asunto. Tal petición no había llegado a tiempo y la causa inicial fue ampliándose con los acontecimientos que tuvieron lugar al mes siguiente. Expuestos todos aquellos disturbios, D. Antonio de Llanos Campomanes, arcediano de Tineo, pidió que se despacharan censuras contra el abad de San Claudio y que ningún otro juez pudiera intervenir en el ya litigio. Enterado el abad, apeló, a la misma instancia, pero en el expediente no aparecen autos y todos los procedimientos son de 1689.

La representación hecha por el cabildo toledano fue respondida por D. Agustín Estefanía ${ }^{61}$, que era uno de los seis canónigos que, junto al abad de San Claudio, había dado posesión del deanato a D. Antonio. El escrito no está fechado, pero, al recoger la sentencia del juez de la nunciatura, D. Gabriel León, tuvo que ser elaborado entre los meses de enero y mayo de $1690^{62}$. Consta de dos partes, en la primera exponía los hechos y en la segunda hacía la réplica. El relato de los acontecimientos, prácticamente, coincide con todos los sucesos y exigencias que aparecen en el expediente de limpieza de D. Antonio y lo que quedó anotado en las actas de las reuniones capitulares.

La exposición de Sr. Estefanía comenzaba con la reacción que había tenido el cabildo tras llegarles la noticia del nombramiento de D. Antonio, que no fue otra que tratar de impedirlo - «movidos de envidia por ser dicho deán de la ciudad y tan emparentado con lo primero de ella y de todo el reino, de edad veintidós años y haberles de presidir el cabildo" ${ }^{63}-$. A tal fin, lo primero que hicieron fue pedir autorización al prelado para que les permitiera hacer una información secreta, que elaboraron a partir de las testificaciones de algunos prebendados. Con los datos recopilados despacharon un informe cuya conclusión era que el aspirante contravenía el estatuto de limpieza. A continuación, enviaron la resolución a Roma, para que el Papa revocara el nombramiento, pero no lo lograron porque el cardenal datario

60. A.H.N. Consejos, 36509, Exp.3.

61. También de este escrito se conserva más de una versión, y, salvando pequeños detalles, el contenido es prácticamente el mismo. R.A.H. Colección Salazar y Castro, 9/35; R.A.H. n ${ }^{\circ}$ 18696; A.H.D.L. Ms. 57.

62. A.H.C.L. Leg. 10.013 .

63. D. Antonio fue bautizado el día 7 de octubre de 1661. Si nos atenemos a la edad media de los canónigos que habían entablado en 1685 y el tiempo que llevaban en el cabildo, los resultados son 42 y 13,5 años, respectivamente. Si prescindimos de los sobrinos del entonces prelado, que habían ingresado con prebenda del mismo en los últimos años, las cifras son algo más elevadas. 
«procuró informante de la calidad del dicho D. Antonio». Esa intervención había retrasado la llegada a León de la bula del candidato más de un año. Cuando al fin pudo presentarse ante cabildo, éste no la admitió, por lo que el aspirante recurrió al tribunal de la nunciatura y después de varias gestiones y «gastos», a aquel no le quedó otro remedio que aceptarla. Posteriormente, demoró las pruebas de limpieza todo el tiempo que le fue posible y cuanto ya no pudo retardarlas más nombraron como instructores a dos canónigos que habían actuado como testigos en las previas, «las secretas» que habían enviado a Roma. El nuevo expediente lo iniciaron con parte de la información del anterior, retirando las declaraciones de los que iban a actuar como informantes. Otras irregularidades cometidas fueron el no respetar dos puntos del reglamento de limpieza de sangre. Concretamente el que mandaba que no podían actuar como calificadores aquellos cuya naturaleza estaba dentro de «10 leguas» de la del calificado, y Reyero «es de un lugar que no dista más de seis o siete leguas de la ciudad» ${ }^{64}$; y el referente a que los investigadores tenían que salir del «cántaro», puesto que el cabildo había escogido a «su gusto la conjuración de los dichos prebendados». Continuaba narrando, que una vez que comenzaron las averiguaciones, al no encontrar a testigos que apoyaran sus objetivos «intentaron inducir» a algunas personas para que declararan contra el pretendiente e, incluso, manipularon las realizadas y despreciaron las que resultaban a favor de deán ${ }^{65}$. También le reprochaba al cabildo que se reuniera para buscar fórmulas que le permitiera alcanzar sus fines o el que decidiera dar largas a la pesquisa, esperando que las vejaciones y los elevados gastos que le estaban ocasionando al aspirante lo condujeran a la ruina, llevaba gastados 6.000 pesos, o a la «muerte». Así mismo, les recriminaba la prolijidad de documentos que le solicitaron para acreditar todas las informaciones o los numerosos desplazamientos, a todas las localidades de procedencia de los antepasados del deán. Todo ello había demorado las pruebas «tres años, cuando podían haberse realizado en un mes», y, de hecho, a lo largo de ese tiempo se habían validado otras, de estatuto riguroso, de familiares de D. Antonio sin encontrar reparos. Una vez que la documentación, con los informes recabados, pasó a la diputación de estatuto y, posteriormente, al cabildo, la intención de sus miembros era entorpecerlas. De hecho, «desconociendo algún prebendado

64. D. Juan Reyero era originario de la localidad leonesa de Campillo, ahora inundada por el embalse del Porma, que estaría en el límite de las 10 leguas y era colindante con Vegamián, dónde ubicaban el origen del apellido Castañón.

65. La implantación de los estatutos de limpieza de sangre, con sus cuestionarios, constituía un buen momento para aflorar viejas rencillas, facilitado por el hecho de que el declarante, al no tener que aportar pruebas de la información que daba, no le resultaría complicado dañar a familias rivales. DOMINGUEZ, 1991: 73-75; PÉREZ, 2006:76. Por otro lado, la ociosidad y la división «entre bandos y el afán disputador y pleitista» estuvo presente en «no pocos cabildos». DOMINGUEZ, 1973: 241; HERNÁNDEZ, 2011:19. 
el fin de la diputación» había sido castigado y multado. Señalaba que si no hubiera intervenido el nuncio no se habrían votado, porque según la mayoría de capitulares si el deán fuera solo canónigo se le aprobaría, pero para deán es muy mozo y no es razón presida a tantos viejos; mientras una minoría opinaba que el cabildo leonés estaba provocando gran «estruendo» en todas las iglesias por razón de condenar a un justo a muerte por mantener el empeño. Una vez se había llegado al momento de la votación, apuntaba, se habían cometido tres irregularidades, la primera había sido no consultar con el prelado, como solía hacerse, porque aquel era partidario de que se aprobaran, ya que era conocedor del motivo que las emponzoñaban e, incluso, había prevenido a todos sus comensales y familiares prebendados que así lo hicieran. La segunda fue trasladar a sala capitular, desde su casa, a un canónigo anciano e incapacitado, en todos los sentidos, para que votara, lo que había causado un gran escándalo en la ciudad. Y, en tercer lugar, que los mismos prebendados que fueron testigos en contra del deán habían actuado como jueces. En el escrutinio se emitieron 45 votos, de los cuales 18 votos le eran favorables y 27 lo reprobaban. A continuación, D. Joaquín Estefanía se preguntaba cómo de aquellos 18 prebendados solamente 6 habían participado en el acto de profesión, la respuesta, a su entender, era que no mantuvieron la «entereza» y acabaron posicionándose del lado contrario. De todo lo expuesto, lo que no tenemos confirmado fue el verdadero posicionamiento del obispo, pues, si bien es cierto, que de los, al menos, tres sobrinos que ya había nombrado para ocupar canonjías solamente uno aparece sentenciado por el nuncio, D. Bernabé Aparicio, también lo es que otros dos canónigos, que entraron por la misma vía, estuvieron condenados por el mismo juez y motivos, D. Ignacio Escobar y D. Francisco García Quiñones. Así mismo, el propio prelado se negó a participar en la votación, para ofrecerle el apoyo que refiere Estefanía e, incluso, a pasar de recomendar, en su momento, la candidatura de Castañón a Su Santidad, parece, según el cabildo, que no entorpeció el expediente «secreto» que formaron en 1685 para enviar a Roma.

Después de la votación, D. Antonio pidió los resultados y los presentó en el tribunal de la nunciatura. El responsable de aquel revocó el dictamen dado por el cabildo, el cual intentó poner un recurso de fuerza, que ni su abogado ni procurador quisieron firmar. Cuando Castañón intentó a notificar al cabildo «el mandamiento immitendo in posesione», aquel resolvió que el procurador general, a quien le correspondía convocarlos, se ausentara para que no pudiera informar del auto. Aquello motivó un nuevo recurso a la nunciatura, para pedir agravatoria, y fue entonces cuando el cardenal Durazzo mandó que se despachara una comisión dirigida al abad del monasterio de San Claudio para que le diera la posesión del deanato. A continuación, relataba los desórdenes acaecidos el día que se hizo efectiva aquella, de forma más moderada que lo había narrado la iglesia toledana o las cartas del doctoral. Finalizó Estefanía esta primera parte del escrito, alegando que todo lo que había escrito se podía documentar con los autos elaborados por el abad de 
San Claudio, los del Alcalde Mayor de la ciudad y la sentencia pronunciada por el licenciado D. Gabriel de León, el 25 de enero de este $1690^{66}$.

En la segunda parte del manifiesto, fue contestando, punto a punto los contenidos de memorial de la Iglesia toledana. Comenzó dudando de la autoría del mismo, pues formado por prebendados «entresacados de los más lúcidos empleos» no justificaban las quejas, o no dejaban claro quién era el objetivo de los reproches, si la media docena de capitulares que apoyaron a $\mathrm{D}$. Antonio, el tribunal de la nunciatura o los ministros reales. También se refirió al Breve Cameral que exhibió el procurador general para que el abad suspendiera la posesión de deán y levantara las censura, apuntado que su contenido era diferente del que referían, concretamente «unas letras de inhibición al señor nuncio, pedidas y sacadas a futuro gravamine». Otra de las cuestiones que le llevaba a mirar con recelo el memorial era que, si como decían, uno de los prebendados había falleció tras ser golpeado: ¿cómo es que no hubo ninguna querella por homicidio? o ¿por qué cuando el doctoral acudió al nuncio, aquel le mando comparecer en León, ante el juez, para que probara su razón y las de los demás culpados?, cosa que no hizo, motivo por el cual, y otras faltas de respeto a sus mandatos, lo mandó encarcelar.

Por supuesto, la visión de los hechos que relató el doctoral, D. Blas Gutiérrez, fue diametralmente opuesta a la de Estefanía. Comenzaba aludiendo a los estatutos de limpieza de sangre y se acogía, para justificar el rechazo de D. Antonio, al artículo en que referían de que abora, ni en tiempo alguno haya habido fama, rumor, ni opinión en contrario. Reconoce que, efectivamente, realizaron un informe para enviar al Papa cuando tuvieron noticia del nombramiento de Castañón, «por mala voz que padecía su familia», pero culpa al mismo de que aquella no llegase a su destino «por habilidad y agencia del provisto». Justificaba el nombramiento de los calificadores - «por sus canas, prudencia, cristiandad y practica en ellas no solo en las santa iglesia, sino en otras comunidades»- y narró, desde una perspectiva totalmente diferente a la de Estefanía, los hechos del 20 de septiembre de 1689, que según él estuvieron cargados de violencia, incitada por el abad y sus seguidores, para, a continuación, rebatir las penas impuestas, por Fray Juan Moniz y el juez apostólico, a los prebendados ${ }^{67}$.

A comienzos de 1690, se hizo un nuevo expediente informativo, en virtud de la comisión del Dr. D. Antonio Llanes Campomanes, Arcediano de Tineo ${ }^{68}$. Entrevistó a unas 36 personas, de las que en torno a la mitad eran clérigos y el resto vecinos de la ciudad, entre los que había escribanos, familiares del Santo Oficio, notarios

66. El contenido de la sentencia puede consultarse en A.U.SA. PV, 2-36 y los reparos a las mismas, realizados por el doctoral D. Blas Gutiérrez, en el A.H.D.L. Ms. 57.

67. A.H.D.L. Ms 57.

68. A.H.C.L. Exp. 571 
y un pequeño número de representantes de las clases populares que, casualmente, estaban cerca de la catedral el día de la posesión y «llamados por la curiosidad» se acercaron a ver que estaba ocurriendo. Unos se centraron más en los disturbios, siguiendo el mismo hilo descriptivo que el doctoral, y otros en la estancia de D. Gabriel León en la ciudad. Respecto a esta segunda cuestión, sus declaraciones salpicaban la imparcialidad la sentencia de ese juez. Debido, según ellos, a que el abad de San Claudio había salido a recibirlo, y a las personas que lo acompañaban, a Mansilla de las Mulas y los había hospedado en el monasterio de San Claudio; grave también era que allí les llevaban la comida de casa de D. Miguel Castañón o que los seis prebendados afines a D. Antonio lo visitaran con frecuencia.

Los tres años de deanato de D. Antonio, fueron de gran tensión. El primer cabildo que se convocó, tras la controvertida toma de posesión, fue el día 3 de noviembre. Le reprocharon que no le importara «la venganza» que D. Gabriel León pudiera ejercer contra sus «hermanos con quienes ha de vivir» o que había venido de Madrid, a petición suya, para pacificar la incómoda situación y, además de no conseguirlo, estaba originando una serie de gastos que se negaban a pagar. Castañón solamente consiguió cobrar lo que le pertenecía de su prebenda, gracias a un auto del nuncio. Los canónigos, que estaban privados de voz y voto en el cabildo, asistían al mismo ignorando el castigo y el deán tenía que soportar como hacían votaciones para emprender diligencias al objeto de desposeerlo cargo, entre ellas, una representación en Roma; o como, la institución exhausta por los gastos, se planteaba la posibilidad de pedir un censo para continuar el pleito. A pesar de las protestas de D. Antonio, obtuvieron el préstamo, por valor de 12.000 ducados, y acordaron pagar los réditos con el rendimiento de las prebendas de los implicados. El dinero se lo prestó el marque de Inicio ${ }^{69}$, lo que aprovechó uno de sus hijos, D. Miguel Quijada, canónigo, para, dos días después de fallecer D. Antonio, el 20 de septiembre de 1693, proponer al cabildo que «le honre con cartas para su santidad y cardenal datario para que el decanato y prebenda que vacó se lo den a su hermano D. Pedro Quijada, residente en Roma», doctorado en la Sapienza en 1694 (Ramis, 2017:202), por supuesto fueron favorables. También doctorado en la Sapienza, nueve años después que (Ramis, 2017:202), tomó posesión de la dignidad el 20 de septiembre de 1694, en la que permaneció hasta 1731.

\section{CONCLUSIÓN}

De todos los expedientes consultados, en los que al candidato se le atribuía algún ancestro judaizante, en ninguno se llevó a cabo una investigación de esa envergadura ni se solicitó tal volumen de documentación. Por su parte, si bien la descripción

69. A.H.C.L. Leg. 10.013 
de la dinámica de los acontecimientos hecha por el Estefanía se puede corroborar con las anotaciones que, de forma más somera, se recogen en las actas capitulares, también lo es el que algunos de los prebendados que, junto al abad de San Claudio, dieron posesión del deanato a D. Antonio habían tenido algunos encuentros con el cabildo, por querer innovar la forma de arrendar las casas de gracia ${ }^{70} \mathrm{y}$, precisamente, uno de ellos fue D. Agustín Estefanía. Este canónigo, además, venía arrastrando otros problemas con la institución desde que aquella le había puesto problemas para tomar posesión de su prebenda, tras ser nombrado por el obispo, y no tuvo inconveniente en protestar, en una reunión capitular, que las pruebas del candidato se estaban dilatando. En cuanto a la participación de «más de 3.000 personas» en los tumultos, la cifra es un tanto exagerada, aunque no dudamos que pudiera haber existido algún tipo de violencia en la toma posesión. Finalmente, señalar, que más que una tendencia de los nuncios a beneficiar a $\mathrm{D}$. Antonio ${ }^{71}$, lo que esconde este largo proceso no se puede calificar como un acontecimiento aislado, sino que es el reflejo de las tensiones capitulares, los bandos que se formaban y las luchas por la independencia de la institución y el poder.

\section{BIBLIOGRAFÍA}

ALVAREZ, C. (1999). Demografía y sociedad. En C. ALVAREZ (Coord.), Historia de León, Vol. II. León, Universidad de León, 280-343.

VAZQUEZ BARRADO, A. (2000). El palacio de la nunciatura de Madrid. Hispania Sacra, 52,507-538;

AUGUSTO RODRIGUES M. (1979). A Inquisição e o Cabido da Sé de Coimbra (158016401). Coimbra: Arquivo Coimbrão.

BARRIO GOZALO, M. (1982). Estudio socio-económico de la Iglesia de Segovia en el siglo XVIII. Segovia: Caja de Ahorro.

CABEZA RODRÍGEZ, A. (1995). Grupos excluidos y formas de asimilación y reproducción social. El ejemplo de la catedral de Palencia en la época moderna. En J. HERNANDEZ (Ed.), Familia y poder. Sistemas de reproducción social en Espala (Siglos XVI-XVIII). Murcia: Universidad de Murcia.

CÁNOVAS BOTÍA, A. (1994). Ange y decadencia de una institución eclesial: El cabildo catedral de Murcia en el siglo XVII. Iglesia y Sociedad, Murcia: Universidad de Murcia.

Castillo Martínez, I. (2008). El poder local en el Antiguo Régimen: la familia Castañón Monroy. Estudios Humanisticos, 7, 201-220.

70. A.H.C.L. Leg. 10.011

71. Hemos indagado si había alguna relación, colegial o de otro tipo, entre los nuncios de ese periodo y D. Antonio, pero no la hemos encontrado, ello no quita que durante la estancia en Roma del candidato pudieran haber establecido alguna conexión, directa o indirecta. DE LA FUENTE,1859:166; RABASCO, 2017:488 y V.V.A.A.,1997:632. 
CONTRETAS CONTRERA, J. (1991). Estructuras familiares y linajes en el mundo judeoconverso. En R. CARRASCO, Solidarités et sociabilités Espagne: XVIe-XXe siècles, París: Les Belles Lettres.

CONTRERAS, J. (1995). Linajes y cambio social: la manipulación de la memoria. Historia Social, 21, 105-124.

DÍAZ IBÁÑEZ J. (2013). Escándalos, ruydos, injurias e cochilladas: prácticas de violencia en el clero catedralicio burgalés durante el Siglo XV. Anuario De Estudios Medievales, 43/2, 543-576.

FELICES DE LA FUENTE, M. M. (2010). «Silencio y ocultaciones en los despachos de los títulos nobiliarios. Análisis crítico de su contenido». Chronica Nova, 36, 229-252.

DOMINGUEZ ORTIZ, A. (1973). Las clases privilegiadas en la España del Antiguo Régimen, Madrid: Istmo.

DOMINGUEZ ORTIZ, A. (1991). La clase social de los conversos en Castilla en la Edad Moderna. Granada: Universidad de Granada.

FUENTE, V. (1859). Historia eclesiástica de España. Tablas cronológicas y adiciones, T. IV. Barcelona: Librería religiosa.

GARCÍA ORO, J. (2004). La reforma tridentina en la iglesia de León. En M. DÍAZ, et al. (Coords). Escritos dedicados a José María Fernández Catón Vol. 1. León: Centro de Estudios e Investigación «San Isidoro», 545-570.

GUILLÉN BERRENDERO, J. A. (2007). La idea de nobleza en Castilla durante el reinado de Felipe II, Valladolid: Universidad de Valladolid.

HERNÁNDEZ FRANCO, J. (1996). Cultura y Limpieza de sangre en la España moderna: puritatis sanguinis. Murcia: Universidad de Murcia.

HERNÁNDEZ FRANCO, J. (2011). Sangre limpia, sangre española. El debate de los estatutos de limpieza de sangres (siglos XVI-XVII). Madrid: Cátedra.

HERNÁNDEZ FRANCO, J. y RUIZ IBÁNEZ, J. J. (2003). Conflictividad social en torno a la limpieza de sangre en la España Moderna. Investigaciones Históricas, 23, 35-56.

IGLESIAS ORTEGA, A. (1996). Análisis sociológico del cabildo compostelano a través de los expedientes de limpieza de sangre. Compostellanum, 3-4, 421-449.

IGLESIAS ORTEGA, A. (2011). Élites eclesiásticas y sociedad en el siglo XVI: la extracción social de los capitulares compostelanos. Estudios Humanisticos. Historia, 10, 11-32.

LATORRE CIRIA, J. M. (1992). Las rentas de la catedral de Huesca y su distribución social (siglos. XVI-XVII). Zaragoza: Institución Fernando el Católico.

MARÍN LÓPEZ, R. (1998). El cabildo de la catedral de Granada en el siglo XVI. Granada: Universidad de Granada.

OLIVARES TEROL, Ma J. (1995). Las canonjías de oficio y oposición en el XVI murciano. Murgetana, 91, 33-50.

PÉREZ ALVAREZ, M.J. (2009). Mortalité et hygiène dans la ville de León au cours de l'époque moderne. Annales de Bretagne et des Pays de l'Onest, 116-2, 54-79.

PÉREZ GARCÍA, J. M. (1999). Demografía leonesa en el Antiguo Régimen (1500-1850). En L.M. RUBIO (Coord.), Historia de León, Vol. III. León: Universidad de León,188-211. 
PÉREZ GARCÍA, M. (2006). Armas, limpieza de sangre y linaje. Reproducción social de familias poderosas de Murcia (siglos XVI.XIX). Murcia: Real Academia Alfonso X el Sabio.

PUENTE BRUNKE, M. (2002). La naturaleza jurídica de la Rota española. Cuadernos doctorales, 19, 233-311.

QUINTANA ANDRÉS, P. (2004). Finis gloriae mundi. Ideología y sociedad en Canarias: los prebendados del Cabildo Catedral durante el Antiguo Régimen (1483-1820). La Laguna: Centro de la Cultura Popular Canaria.

RABASCO FERREIRA R. (2017). La Representación Pontificia En La Corte Española. Historia De Un Ceremonial y Diplomacia. Madrid: Sanz y Torres.

RAMIS BARCELÓ, R. (2017). Doctores hispanos en leyes y cánones por la Universidad de la Sapienza de Roma (1549-1774). Madrid: Dykinson.

RIBERIRO DA SILVA, H. (2010). O Cabido da Sé de Coimbra. Os Homens e a Instituição 1620-1670. Lisboa: Imprensa de Ciências Sociais.

SERRANO REDONNET, J. A. (1967). Poético elogio de los linajes leoneses y «generaciones» de la casa de la Vecilla. Hidalguía, 84, 605-640.

SORIA MESA, E. (2004). «Genealogía y poder. Invención del pasado y ascenso social en la España Moderna». Estudis. Revista de Historia Moderna, 30, 21-55.

SICROFF, A. (1985). Los estatutos de limpieza de sangre. Controversia entre los siglos XV y XVII. Madrid: Taurus. V.V.A.A. (1997), La crisis de la Hegemonía española en el siglo XVII. Madrid: Rialp.

VÁZQUEZ LESMEN, R. (1999). El cabildo catedralicio cordobés en tiempos de Felipe II: limpieza de sangre y elite de poder. En J. L. Pereira (Coord.), Actas de la V Reunión Cientifica de la Asociación Española de Historia Moderna.T.I. Cádiz: Universidad, 597-306.

VILLACORTA RODRÍGUEZ, T. (1974). El cabildo de la catedral de León. Estudio Histórico-jurídico, siglos XII-XIX. León: Centro de Estudios e Investigación San Isidoro.

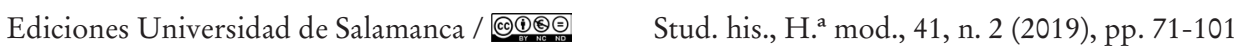

